Glucose inhibits human placental GH ... [J Clin Endocrinol Metab. 1995] - PubMed -... Page 1 sur 1

\begin{tabular}{|l|l|l|l|l|l|}
\hline PubMed $\quad-$ & Search \\
\hline
\end{tabular}

Display Settings: Abstract

J Clin Endocrinol Metab. 1995 May;80(5):1743-6

\title{
Glucose inhibits human placental GH secretion, in vitro.
}

Patel N, Alsat E, Igout A, Baron F, Hennen G, Porquet D, Evain-Brion D.

INSERM U 427, Ecole Normale Supérieure, Paris, France.

\begin{abstract}
Human placenta specifically expresses the GH-V gene leading to the production of placental Growth Hormone (PGH). During pregnancy, $\mathrm{PGH}$ levels increase progressively in maternal blood, but its regulation remains unknown. In this study the effect of glucose on PGH secretion by human term placenta was tested, in vitro, by means of two different experimental models: organ culture of villous tissue and primary culture of isolated cytotrophoblasts. $\mathrm{PGH}$ was assayed in the culture medium by an immunoradiometric assay using a specific PGH monoclonal antibody. The presence of glucose $(25 \mathrm{mmol} / \mathrm{L})$ in the culture medium significantly inhibited $(p<0.001)$ the secretion of PGH by either placental villous explants or by cultured trophoblast cells. This inhibitory effect of glucose on PGH secretion was dose-dependent. More than $50 \%$ inhibition being observed with $5.5 \mathrm{mmol} / \mathrm{L}$. In the same conditions, the daily production of $\mathrm{hPL}$ and hCG, were unmodified. Furthermore, the glucose-induced inhibition of PGH secretion was more effective when cultured trophoblast cells are differentiated into syncytiotrophoblast. This study demonstrates, for the first time, that among the gestational polypeptide hormones secreted by the human placenta, only $\mathrm{PGH}$ secretion is modulated by glucose, suggesting a key metabolic role for this hormone during pregnancy.
\end{abstract}

PMID: 7745029 [PubMed - indexed for MEDLINE]

Publication Types, MeSH Terms, Substances

LinkOut - more resources 
This document was created with Win2PDF available at http://www.win2pdf.com. The unregistered version of Win2PDF is for evaluation or non-commercial use only. This page will not be added after purchasing Win2PDF. 